\title{
Geosciences

\section{Metal Bioavailability Potential of São Francisco River Sediments in Três Marias (Minas Gerais - Brazil)}

Potencial de biodisponibilidade de metais nos sedimentos do rio São Francisco em Três Marias (Minas Gerais - Brasil)

\begin{abstract}
Afonso Henriques Martins
Professor

Associado da Universidade Federal de

Minas Gerais

Belo Horizonte, Minas Gerais, Brasil

ahmartin@demet.ufmg.br

Débora Fernandes Almeida

Engenheira de Minas da Votorantim

Metais Zinco S.A.

Belo Horizonte, Minas Gerais, Brasil

debora.almeida@vmetais.com.br
\end{abstract}

Luciano Rodrigues Gomes Santos

Químico Industrial da Golder Associates Brasil

Belo Horizonte, Minas Gerais, Brasil

Isantos@golder.com.br

Thiago Toussaint Marcelino Moreira

Engenheiro Ambiental da Golder Associates Brasil Belo Horizonte, Minas Gerais, Brasil

ttmoreira@golder.com.br

\begin{abstract}
Sediment contamination by metals is very common and frequently researched worldwide with the objective of assessing the environmental impact of these contaminants. The bulk metal concentration in sediments is not enough for assessing toxicity and therefore, needs additional research and assays. To estimate the potentially bioavailable fraction of the metals in the sediment, the acid-volatile sulfides / simultaneously extracted metals (AVS/SEM) method was used. Seven samples in duplicate were collected from the São Francisco River and its tributary, near a zinc metallurgical plant in the city of Três Marias (MG). The AVS/SEM results suggest that, although the bulk metal concentrations are above TEL (Threshold Effects Level: A chemical concentration above which some adverse effect to biota is expected), samples from the São Francisco River presented relatively low potential for bioavailability (uncertain toxicity). These results should be taken into consideration before deciding about contaminated sediment management.
\end{abstract}

Keyword: AVS-SEM, bioavailability, metals, São Francisco River

\section{Resumo}

Contaminação de sedimentos de corrente por metais é comum e tem sido alvo de diversas pesquisas no mundo, com o objetivo de determinar o impacto ambiental. Somente o estudo da concentração total de metais nos sedimentos não é suficiente para uma avaliação realista da toxicidade presente. Entre os vários estudos recomendados para melhor avaliar o impacto ambiental dos metais, encontram-se os ensaios de caracterização geoquímica da concentração de sulfetos voláteis por acidificação e de metais simultaneamente extraídos (SVA-MES), que é utilizada para determinar a fração potencialmente biodisponível de metais. Sete amostras foram coletadas no leito do Rio São Francisco e tributário próximo a uma planta metalúrgica de zinco no município de Três Marias MG. Ensaios de caracterização geoquímica do tipo SVA-MSE dessas amostras sugerem que, apesar de a concentração de metais totais estar acima do nível 2 (limiar acima do qual prevê-se um provável efeito adverso à biota, segundo a Resolução CONAMA 344/2004, que classifica sedimentos, o potencial de biodisponibilidade de metais nessas amostras é relativamente baixo para as amostras do rio São Francisco (toxicidade incerta). Esses resultados devem ser levados em consideração na decisão quanto à gestão dos sedimentos contaminados.

Palavras chave: MES-SVA, biodisponibilidade, metais, Rio São Francisco. 


\section{Introduction}

In assessing metal contamination impacts upon river bed sediments, a clear relationship has not been proven between total metal concentration and its potential impact on the biota. Many studies demonstrate that metal sulfide formation and association with

Concentration of sulfides in sediments may be measured by adding chloric

The volatilized sulfides are named AVS. The bivalent metals $(\mathrm{Cd}, \mathrm{Cu}, \mathrm{Ni}, \mathrm{Pb}$ e $\mathrm{Zn}$ ) extracted by the acid, represented in the reaction (2) as $\mathrm{Me}^{2+}{ }_{(a q)}$, are named SEM. SEM includes metals other than those associated to sulfide, for example, metals associated to organic matter and oxides.

Many studies demonstrate that sediments are not toxic to aquatic organisms when the concentration of AVS exceeds the molar sum of SEM (Ditoro et al., 1990, 1991, 2000 referenced by USEPA, 2005; iron (Fe), manganese ( $\mathrm{Mn}$ ) oxides, hydroxides, and organic compounds regulate the bioavailability and toxicity of metals in river sediments (ICMM, 2007).Potential metal bioavailability in river bed sediments may be assessed by a method known as AVS-SEM (Acid

$$
\mathrm{Me}^{2+}{ }_{(\mathrm{aq})}+\mathrm{S}_{(\mathrm{aq})}^{2-} \rightarrow \mathrm{MeS}_{(\mathrm{s})}
$$

acid, which volatilizes sulfide according to the following reaction (2) (GOLDER,

$$
2 \mathrm{HCl}_{(\mathrm{aq})}+\mathrm{MeS}_{(\mathrm{s})} \rightarrow \mathrm{Me}^{2+}{ }_{(\mathrm{aq})}+2 \mathrm{Cl}_{(\mathrm{aq})}^{-}+\mathrm{H}_{2} \mathrm{~S}_{(\mathrm{g})}
$$

Allen et al, 1993 referenced by Golder, 2007; Ankley et al, 1996, Pesch et al. 1995 e Hansen et al, 1996 referenced by ICMM, 2007). Therefore, sediments are non-toxic when $\Sigma$ SEM - AVS $=0$. When assessing the toxicity of a specific metal, its competition with other metals that bind with sulfides and their solubility must be considered. From less soluble to more soluble: $\log K_{C u}<\log K_{\mathrm{Pb}}<\log K_{C d}$ $<\log \mathrm{K}_{\mathrm{Zn}}<\log \mathrm{K}_{\mathrm{Ni}}$. Therefore, AVS will preferably associate with copper $(\mathrm{Cu})$, if present in the environment. In case of
Volatile Sulfides / Simultaneously Extracted Metals), which is based on the fact that some bivalent metal cations $(\mathrm{Cd}, \mathrm{Cu}, \mathrm{Ni}, \mathrm{Pb}, \mathrm{Zn})$ are little soluble and therefore precipitate- as secondary metal sulfide, according to the following reaction (1) (ICMM, 2007):

\section{7):}

AVS excess, after association with all copper $(\mathrm{Cu})$, other metals will associate according to their solubility constant. (ICMM, 2007)

SEM excess does not necessarily mean that metals are toxic to biota. Other mechanisms for attenuating toxicity may be present, for example, sorption to organic matter (TOC). From empiric data, the following toxicity thresholds were established, as a function of excess SEM normalized by TOC (Ditoro et al., 1991, 2000 referenced by USEPA, 2005):

If ( $\Sigma$ SEM - AVS $) / f_{\text {TOC }}<130 \mu \mathrm{mol} / \mathrm{gTOC}$, then toxicity is improbable.

If $(\Sigma \mathrm{SEM}-\mathrm{AVS}) / f_{\mathrm{TOC}}>3.000 \mu \mathrm{mol} / \mathrm{gTOC}$, then toxicity is probable.

In the intermediate cases, toxicity is uncertain.

Within this article, the AVS-SEM as- says include the assessment of metals ( $\mathrm{Zn}$, $\mathrm{Cd}, \mathrm{Cu}, \mathrm{Pb}, \mathrm{Ni}$ ) potential bioavailability in sediments of both Consciencia Creek and
São Francisco River (Tres Marias/Minas Gerais/Brazil).

\section{Materials and Methods}

The sediments samples were collected from the bed of both the São Francisco River and its tributary Consciencia
Creek, at the sites described below (Figure 1), which are located in city of Três Marias (Minas Gerais/Brazil). Sampling occurred in October 2008. The studied area is under influence of a zinc metallurgical company.

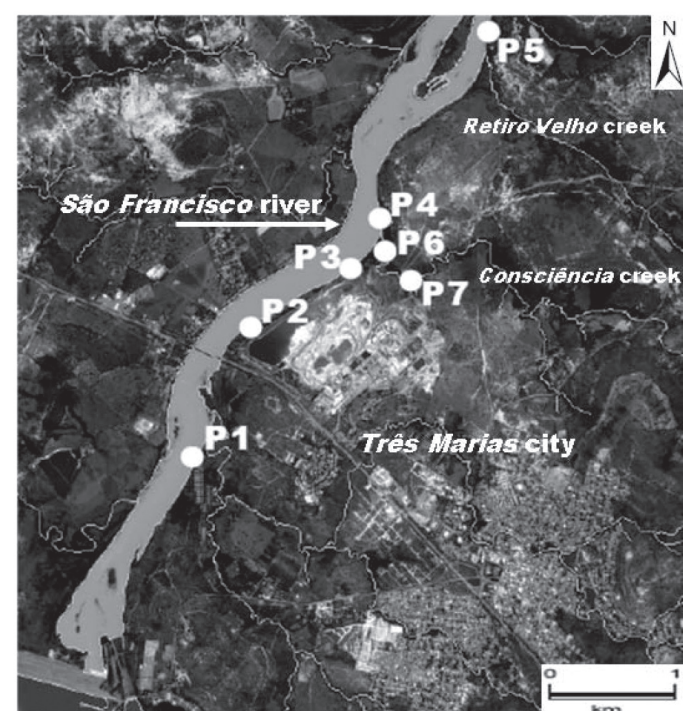

Figure 1

Stretches of São Francisco River and Consciencia Creek, where sediments samples were collected (Tres Marias - MG), and the respective description of samples'

\begin{tabular}{|c|c|c|}
\hline Sample & Location & Description \\
\hline P1 & $18^{\circ} 11^{\prime} 59,6^{\prime \prime} \mathrm{S} ; 45^{\circ} 15^{\prime} 18,5^{\prime \prime} \mathrm{W}$ & São Francisco river, before the metallurgical industry. \\
\hline P2 & $18^{\circ} 11^{\prime} 8,8$ "'S; 4514'55,2”W & São Francisco river, in front of tailings dump. \\
\hline P3 & $18^{\circ} 10^{\prime} 52,2^{\prime \prime} \mathrm{S} ; 45^{\circ} 14^{\prime} 24,6^{\prime \prime} \mathrm{W}$ & São Francisco river, after metallurgy's effluent discharge. \\
\hline P4 & $18^{\circ} 10^{\prime} 43,1^{\prime \prime} S ; 45^{\circ} 14^{\prime} 15,7^{\prime \prime} \mathrm{W}$ & São Francisco river, at Consciencia creek. \\
\hline P5 & $18^{\circ} 09^{\prime} 59,5^{\prime \prime} \mathrm{S} ; 45^{\circ} 13^{\prime} 48,1^{\prime \prime} \mathrm{W}$ & São Francisco river, at Retiro Velho creek. \\
\hline P6 & $18^{\circ} 10^{\prime} 47,9 ” \mathrm{~S} ; 45^{\circ} 14^{\prime} 17,6^{\prime \prime} \mathrm{W}$ & Consciencia creek, near São Francisco river. \\
\hline P7 & $18^{\circ} 10^{\prime} 53,4^{\prime \prime} \mathrm{S} ; 45^{\circ} 14^{\prime} 17,3^{\prime \prime} \mathrm{W}$ & Consciencia creek, inside metallurgical industry. \\
\hline
\end{tabular}
location. 
For sampling the sediments, a 4.5L Van Veen dredge (opened dredge reaches an area of approximately $300 \mathrm{~cm}^{2}$ ) was used. Approximately $20 \mathrm{~kg}$ of sediments were sampled in each location. The material was homogenized, divided into smaller samples and stored under refrigeration.

Duplicate samples were collected in order to guarantee adequate quality control (QA/QC) for sampling and

\subsection{Bulk metals}

Samples were prepared according to the Standard 3050B Method (Apha, 2005; USEPA, 1996), which consists of multi-acid digestion $\left(\mathrm{HNO}_{3}, \mathrm{HCl}\right.$ and $\left.\mathrm{H}_{2} \mathrm{O}_{2}\right)$. This procedure is also recommended by CONAMA (2009).

\subsection{AVS-SEM assays}

Samples were submitted to the procedures established by USEPA (1991), in order to quantify acid volatile sulfides (AVS) and simultaneously extracted metals (SEM). Sediments (2g) were weighed and placed into reaction flasks with $100 \mathrm{~mL}$ of deionized water, then submitted to agitation and to a $\mathrm{N}_{2}$ flow. Next $20 \mathrm{~mL}$ of HCL $(6 \mathrm{M})$ were added using a syringe. The volatilized sulfides $\left(\mathrm{H}_{2} \mathrm{~S}\right)$ were purged from reaction flask by $\mathrm{N}_{2}$ and trapped into a receptor flask with a $\mathrm{NaOH}$ solution. The solution which corresponds to SEM was filtered through a

\section{Results}

\subsection{Bulk metals}

Contamination or bulk metals were compared to Brazilian legislation - CONAMA (2004) which adopted guidelines from the Canadian Council of Ministers of the Environment - CCME: Level 1 corresponds to TEL (threshold effect level), Level 2 corresponds to PEL (probable effect level) (CCME, 1999).

The RPD's (Relative Percentage Difference) analyses are presented in Table 1. The duplicates of P3 and P4 varied little analysis methods. Samples P3 and P4 were homogenized and divided into two samples (duplicates) as a quality control for chemical analysis and ecotoxicity assays. P2 was sampled twice, i.e. technically the two are not the same sample, but they were named P2 and P2 duplicate and were used as a quality control for the sampling procedure. $\mathrm{Du}$ plicate results were analyzed according to the methodology proposed by USEPA
(1995) using the RPD (Relative Percentage Difference) index, which should be below $20 \%$ so that the QA/QC is considered adequate. Sediment samples were not ground, because the aim was to assess bioavailability rather than total metal content and therefore, the difference between the duplicates may be more than $20 \%$. A higher difference is expected between $\mathrm{P} 2$ and $\mathrm{P} 2$ duplicate because they are not the same sample.
The metals zinc $(\mathrm{Zn})$, cadmium $(\mathrm{Cd})$, copper $(\mathrm{Cu})$, lead $(\mathrm{Pb})$ and nickel $(\mathrm{Ni})$ were quantified by ICP-OES (inductively coupled plasma optical emission spectrometer), model Optima 5300DV/ Perking Elmer, according to the Stan- dard Methods 3030 and 3120 (APHA, 2005). Quality control consisted of standard samples analyses. Results were accepted when recovery rates from standard samples analyses ranged between 80 and $100 \%$.
$0.45 \mu \mathrm{m}$ membrane and submitted for determination of the metals $(\mathrm{Cu}, \mathrm{Cd}, \mathrm{Pb}$, $\mathrm{Ni}, \mathrm{Zn}$ ), according to the Number 3030 and 3120 Standard Methods for the Determination of Water and Wastewater SMEWW (APHA, 2005). For the sulfide determination, the colorimetric method with methylene blue was used: SMEWW 4500S2-D. Total organic carbon was analyzed in a Shimadzu's TOC, according to SMEWW 5530C.

The molar sum of the simultaneously extracted metals (SEM) was subtracted from the molar concentration of acid volatile sulfides (AVS). When the calculations ( $\Sigma$ SEM-AVS) resulted in positive numbers, the results were normalized for total organic carbon $\left(f_{\text {TOC }}\right)$ and compared to the constraints described in USEPA (2005). These constraints were derived from acute toxicity experiments conducted by DiToro (1990, 1991 and 2000), by compiling toxicity data from literature and establishing two uncertainty bounds that correspond to the concentration range where it is $90 \%$ certain that sediments may either be toxic or non-toxic (USEPA, 2005).
(<+-20\%) for most metals if compared to its original analysis, except zinc $(\mathrm{Zn})$ in P3 (53\%) and nickel (Ni) in P4 (40\%). The P2 duplicate, however, varied more than $20 \%$ for most metals (up to $126 \%$ ) because it was another sample from the same location and not the same sample divided into two, reflecting variability between samplings.

According to CHAPMAN and ANDERSON (2005), river bed sediments are a complex matrix in which contaminant concentrations frequently oscillate. Therefore, the analytical results were considered valid for all sediments samples.

The results for bulk metals are plotted in Figure $2(a, b)$. For a better visualization, the results were normalized according to CONAMA (2004) Levels 1 and 2 . Standard sample recovery rates varied between 80 and $100 \%$, assuring quality control. 


\begin{tabular}{llllll}
\hline Samples & $\mathbf{C d}$ & $\mathbf{C u}$ & $\mathbf{N i}$ & $\mathbf{P b}$ & $\mathbf{Z n}$ \\
\hline & $\mathrm{mg} / \mathrm{kg}$ & & & & \\
\hline P2 & 18.7 & 126 & 8 & 353 & 1572 \\
\hline P2 (duplicate) & 5.9 & 28.8 & 8 & $\mathrm{NA}$ & 1199 \\
\hline RDP & $\mathbf{1 0 4 \%}$ & $\mathbf{1 2 6} \%$ & $\mathbf{0 \%}$ & $\mathbf{N A}$ & $\mathbf{2 7 \%}$ \\
\hline P3 & $<3$ & 17.4 & 15 & 22 & 315 \\
\hline P3 (duplicate) & $<3$ & 15.8 & 15 & 19 & 183 \\
\hline RDP & $\mathbf{0 \%}$ & $\mathbf{1 0 \%}$ & $\mathbf{0 \%}$ & $\mathbf{1 5 \%}$ & $\mathbf{5 3 \%}$ \\
\hline P4 & 7 & 15.7 & 6 & 48 & 1255 \\
\hline P4 (duplicate) & 6.2 & 13.7 & 4 & 43 & 1156 \\
\hline RDP & $\mathbf{1 2 \%}$ & $\mathbf{1 4 \%}$ & $\mathbf{4 0 \%}$ & $\mathbf{1 1 \%}$ & $\mathbf{8 \%}$ \\
\hline
\end{tabular}

Table 1

Analysis of Relative Percentage Difference - RPD - for bulk metals concentration in duplicate samples (P2, P3 and P4 - see Figure 1 for location) (October, 2008)

Figure $2 \mathrm{a}$

Level 2 (CONAMA, 2004) normalized bulk metal concentration ( $\mathrm{Zn}, \mathrm{Cd}, \mathrm{Pb}, \mathrm{Cu}$ and $\mathrm{Ni}$ ) in the samples collected from São Francisco River and tributary (see Figure 1 for samples' location

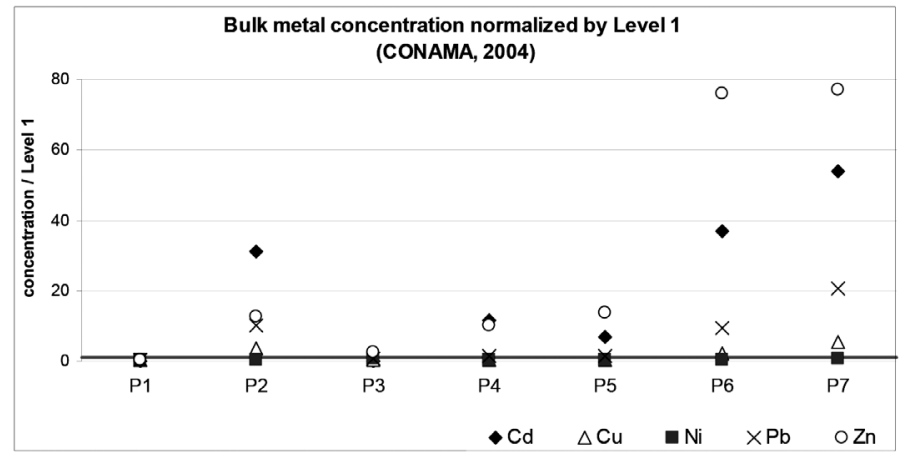

Metal concentrations in the reference sample (P1) were below Level 2 and 1 (CONAMA, 2004), i.e. the sample was not contaminated. On the other hand, the samples P2, P4, P5, P7 and P6 resulted in zinc and cadmium concentrations above Level 2. The samples P2, P7 and P6 also contained lead above Level 2 (CONAMA,

\subsection{AVS-SEM}

The RPD (Relative Percentage Difference) analyses are presented in Table 2. The duplicate of P4 varied little $(<20 \%)$ for most metals if compared to its original analysis. Duplicate of P2 varied up to $41 \%$, less than in the bulk metal analysis by the $3050 \mathrm{~B}$ method. P3, on the other hand, varied $118 \%$ for the metal zinc $(\mathrm{Zn})$ and the reason was not determined. Some of it could be attributed to the fact that the sample was not ground, but if so, this would also be
2004). The sample P3 was above Level 1, but not above Level 2 .

An isolated analysis of bulk metal concentration led to the preliminary conclusion that most of sediment samples contained metal concentrations above the threshold in which adverse biological effects are probably observed, more

reflected in the bulk metal analysis. The uncertainty intrinsic in the SEM-AVS method is a more probable explanation.

The results for SEM-AVS are presented in Table 3. The reference sample P1 presented negative results; therefore, toxicity is not expected. The other samples presented positive results, which were TOC normalized and presented in Figure 3, following the guidelines proposed by Ditoro et al (1990, 1991 and 2000). The excess SEM of São Francisco
Figure $2 b$

Level 1 (CONAMA, 2004) normalized bulk metal concentration ( $\mathrm{Zn}, \mathrm{Cd}, \mathrm{Pb}, \mathrm{Cu}$ and $\mathrm{Ni}$ ) in the samples collected from São Francisco river and tributary (see Figure 1 for samples' location)

frequently presenting the metals zinc $(\mathrm{Zn})$ and cadmium (Cd), except for samples P1 and P3. However, these results must be jointly analyzed with information on bioavailability to support a more realistic conclusion on the geochemical behavior of sediments and the consequent impact on aquatic life.

River sediment samples consists essentially of zinc $(\mathrm{Zn})$ and nickel $(\mathrm{Ni})$, more soluble than lead $(\mathrm{Pb})$, copper $(\mathrm{Cu})$ and cadmium $(\mathrm{Cd})$, which apparently are in the AVS form and consequently unavailable to the biota. The sample P7, from the Consciencia Creek, behaves differently. The AVS present is sufficient for linking copper $(\mathrm{Cu})$ and part of the lead $(\mathrm{Pb})$. The excess SEM of sample P7 consists of lead $(\mathrm{Pb})$, cadmium $(\mathrm{Cd})$, zinc $(\mathrm{Zn})$ and nickel $(\mathrm{Ni})$. 
Table 2

Analysis of Relative Percentage Difference - RPD - for AVS and SEM results in duplicate samples (P2, P3 and P4 - see Figure 1 for location) (October, 2008)

Table 3

Concentrations of simultaneously extracted metals (SEM) and acid volatile sulfides

(AVS) in the samples collected from São Francisco River and tributary (see Figure 1 for samples' location) (October, 2008)

Figure 3

Excess of simultaneously extracted metals ( $\Sigma$ SEM-AVS) normalized by total organic carbon (TOC) in the samples collected from São Francisco River and tributary (see Figure 1 for samples' location)

Results of the AVS-SEM assays suggest that the adverse biological effects are not as certain as the bulk metal concentration results previously suggested. According to the SEM-AVS assays, most of the samples present partial metal concentration in the sulfide form, which is unavailable to the biota.

\section{Conclusion}

Geochemical assays such as AVSSEM are important for assessing the potential bioavailability of metals in river bed sediments, rather than simply analyzing bulk metal concentrations. However, further studies should be developed and jointly analyzed before taking any decisions concerning remediate actions. Stud-

\section{References}

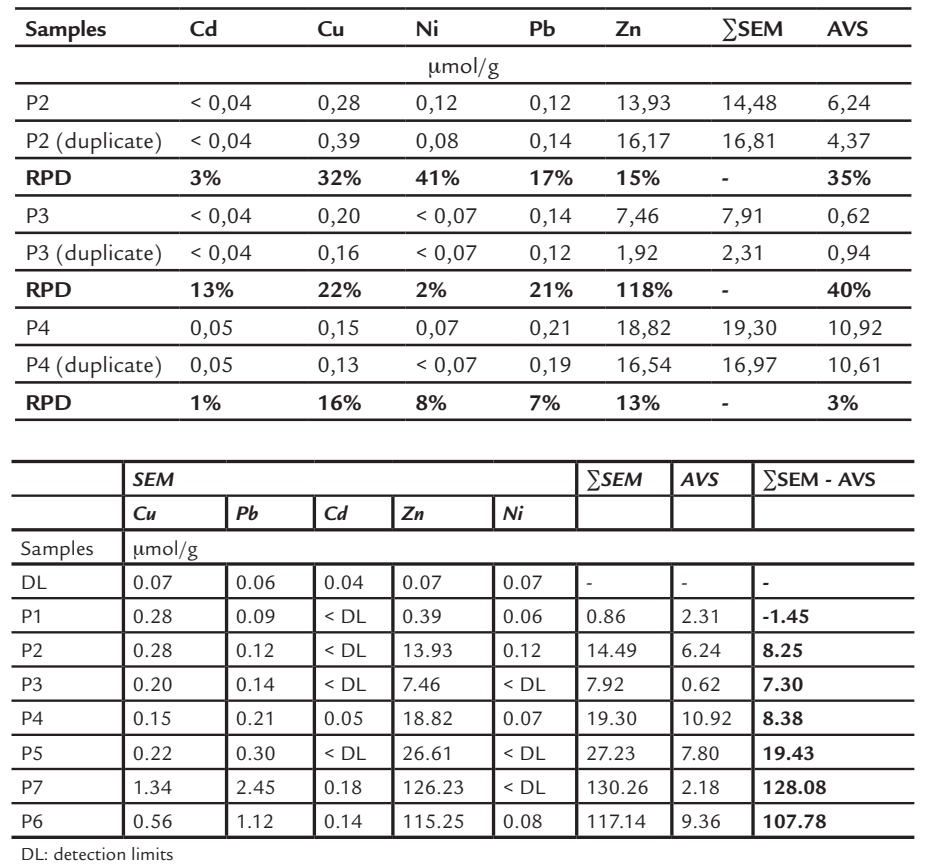

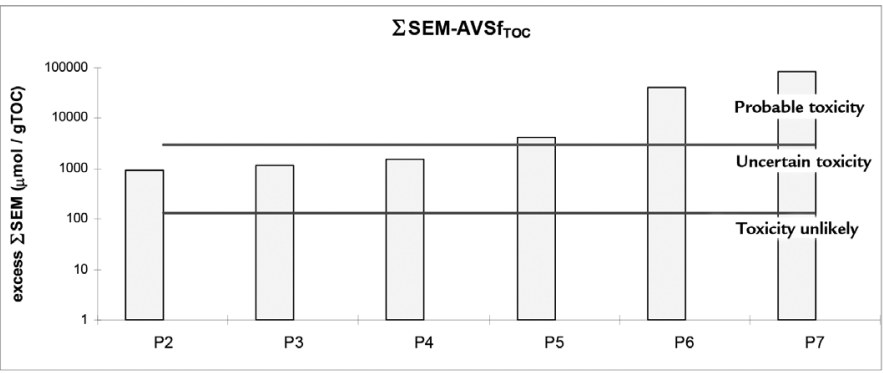

Therefore, toxicity in most samples is uncertain, according to the guidelines proposed by Ditoro et al (1990, 1991 and 2000), except for samples P7, P6 and P5.

A definitive conclusion concerning the environmental impact from sediments has not yet been achieved.

Therefore, further studies are encouraged, such as eco-toxicity assays and benthonic community assessment. Conclusions may be more assertive when different results are jointly analyzed. The weight-of-evidence approach enables an overall analysis of many different results (Chapman and Anderson, 2005). ies that directly measure contamination effects on biota are preferable (eco-toxicity assays and benthos studies).

Results associated with this article suggest that sediments from the Consciencia Creek are likely to cause adverse effects on the biota. As such, some way to solve the contaminant problem should be sought. Concerning the sediments from the São Francisco River, further studies should be developed in order to support any decision concerning contaminant remediation. The weight-of-evidence approach (Chapman and Andersson, 2005) is suggested to support the overall analysis of all available data.

ALMEIDA, D. F., Gestão ambiental dos sedimentos de corrente do rio São Francisco e afluente na região de Três Marias/ Minas Gerais. Belo Horizonte: Universidade Federal de Minas Gerais, 2010. (Thesis- Doctorate in Minas and Metallurgy Engeneering). 94 p.

ALLEN, H. E. et al. Analysis of acid-volatile sulfide (SVA) and Simultaneously Extracted Metals (SEM) for the estimation of potential toxicity in aquatic sediments. Environmental Toxicology and Chemistry, [S.1], v. 12, p. 1441-1453, 1993 apud 
GOLDER ASSOCIATES BRASIL. Zoneamento da distribuição da contaminação de sedimentos do leito submerso do rio São Francisco. Technical report prepared to Votorantim Metais Zinco S.A.). Belo Horizonte, Minas Gerais, 2007.

ANKLEY, G.T. Evaluation of metal/acid-volatile sulfide relationships in the prediction of metal bioaccumulation by benthic macroinvertebrates. Environmental Toxicology and Chemistry, [S.1],

v. 15, n. 12, p. 2138-2146. 1996 apud [ICMM] International Council of Mining and Metals. Metals Environmental Risk Assessment Guidance - MERAG. London, England, 2007.

[APHA] American Public Health Association. Standard Methods for the Examination of Water and Wastewater, SMEWW. Washington, United States of America, 2005. $21^{\mathrm{a}}$ ed.

[CCME] Environment Canada. Canadian Council of Ministers of the Environment. Canadian sediment quality guidelines for the protection of aquatic life: summary tables. Updated. Winnipeg, Canada, 2002. In: Canadian Council of Ministers of the Environment. Canadian Environmental Quality Guidelines, Winnipeg, Canada, 1999. Available in: <http://ceqg-rcqe.ccme.ca/>. Accessed in: 30 July 2010.

CHAPMAN, P.M., ANDERSON J. A decision-making framework for sediment Contamination. Integrated Environmental Assessment and Management, v. 1, n. 3, p. 163-173. [S.1], 2005.

[CONAMA] Brazil. Ministério do Meio Ambiente. Conselho Nacional do Meio Ambiente. Resolução no 344, de 2004. Estabelece diretrizes gerais e procedimentos mínimos para avaliação do material a ser dragado de áreas brasileiras e dá outras providências. Brasília, DF, March, 2004.

[CONAMA] Brazil. Ministério do Meio Ambiente. Conselho Nacional do Meio Ambiente. Resolução no 420, de 2009. Dispõe sobre critérios e valores orientadores de qualidade do solo quanto à presença de substâncias químicas e estabelece diretrizes para o gerenciamento ambiental de áreas contaminadas por essas substâncias em decorrência de atividades antrópicas. Brasília, DF, December, 2009.

DITORO, D. M. et al. Predicting the toxicity of metals in sediments using SEM and AVS, [S.l., s.n.], 2000 apud [USEPA] Environmental Protection Agency. Procedures for the derivation of equilibrium partioning sediments benchmarking for the protection of benthic organisms: metal mixtures $(\mathrm{Cd}, \mathrm{Cu}, \mathrm{Pb}, \mathrm{Ni}, \mathrm{Ag}, \mathrm{Zn})$. Washington, United States of America, 2005.

DITORO D. M. et al. Technical basis for establishing sediment quality criteria for nonionic organic chemicals using equilibrium partitioning. Environmental Toxicology and Chemistry, v.10, p. 1541-1583, [S.l], 1991. apud [USEPA] Environmental Protection Agency. Procedures for derivation of equilibrium partioning sediment benchmarks (ESBs) for the protection of benthic organisms: metal mixtures (cadmium, copper, lead, nickel, silver and zinc). Washington, United States of America, 2005.

DITORO, D. M. et al. Toxicity of cadmium in sediments: the role of acid volatile sulphide. Environmental Toxicology and Chemistry, v.9, p. 1487-1502, [S.1], 1990 apud [USEPA] Environmental Protection Agency. Procedures for derivation of equilibrium partioning sediment benchmarks (ESBs) for teh protection of benthic organisms: metal mixtures (cadmium, copper, lead, nickel, silver and zinc). EPA-600-R02-011. Washington, Estados Unidos da América, 2005.

[GOLDER]. Golder Associates Brasil. Zoneamento da distribuição da contaminação de sedimentos do leito submerso do rio São Francisco. Belo Horizonte, Minas Gerais, 2007. Relatório técnico (elaborado para Votorantim Metais Zinco S.A.).

HANSEN, D.J. et al. Predicting the toxicity of metal-contaminated field sediments using interstitial concentrations of metals and acid-volatile sulfide normalizations. Environmental Toxicology and Chemistry, v.15, n.12, p. 2080-2094, [S.1], 1996 apud [ICMM] International Council of Mining and Metals. Metals Environmental Risk Assessment Guidance - MERAG. Londres, Inglaterra, 2007.

[ICMM] International Council of Mining and Metals. Metals Environmental Risk Assessment Guidance - MERAG. London, 2007.

$\mathrm{PESCH}, \mathrm{C}$. E. et al. The role of acid volatile sulfide and intersticial water metal concentrations in determining bioavailability of cadmium and nickel from contaminated sediments to the marine polychaete neanthes arenaceodentata. Environmental Toxicology and Chemistry. v.14, n.1, [S.1], 1995 
[USEPA] Environmental Protection Agency. Method 3050 B: Acid digestion of sediments, sludges, and soils. Washington, United States of America, 1996.

[USEPA] Environmental Protection Agency. QA/QC Guidance for Sampling and Analysis of Sediments, Water, and Tissues for Dredged Material Evaluations. Washington, United States of America, 1995.

[USEPA] Environmental Protection Agency. Draft Analytical Method for Determination of Acid Volatile Sulfides in Sediment. Washington, United States of America, 1991.

Received: 09 March 2012 - Accepted: 24 February 2014. 